\title{
THE EFFECTS OF COMPOSITION OF SHIELDING GAS MIXTURE ON THE MICROSTRUCTURE AND TOUGHNESS OF MICROALLOYED STEEL WELD METAL
}

\author{
Olivera Popović ${ }^{1}$ \\ Radica Prokić Cvetković', \\ Nenad Milošević1, \\ Dragan Cvetković
}

\author{
${ }^{1}$ University of Belgrade, \\ Faculty of Mechnical Engineering, \\ Kraljice Marije 16, Belgrade, Serbia \\ ${ }^{2}$ Singidunum University, \\ Faculty of Informatics and Computing, \\ 32 Danijelova Street, Belgrade, Serbia
}

Correspondence:

Olivera Popović

e-mail:

opopovic@mas.bg.ac.rs

\begin{abstract}
:
It has been established that the ferrite structure occurring in different morphologic forms dominates in weld metal of microalloyed steel. Acicular ferrite is the most desirable morphology of ferrite, so this paper analyses influence of the composition of gas mixture on the ferrite modification in the weld metal, specially on the morphology of acicular ferrite. At the same time, this morphological form of ferrite is very significant, because it has great influence on the mechanical properties, especially toughness. Five different gas mixtures $\left(\mathrm{Ar}, \mathrm{CO}_{2}, \mathrm{O}_{2}\right.$ ) were used to determine the optimal gas shielded metal arc process. For investigated microalloyed steel, the optimum gas mixture has been established $\left(5 \% \mathrm{CO}_{2}, 0.91 \% \mathrm{O}_{2}\right.$, balance $\mathrm{Ar}$ ), providing maximum impact energy due to microstructure, consisting predominately of acicular ferrite.
\end{abstract}

Key words:

microstructure, toughness, microalloyed steel, mixture of shielded gases, acicular ferrite.

\section{Acknowledgment}

The research was perfomed within the frame of the national project TR35024 financed by Ministry of Science of the Republic of Serbia.

\section{INTRODUCTION}

Welding by metal arc process with mixture of shielded gases has been increasingly popular in recent years. Gaseous mixtures are physical mixtures of various gasses. Theoretically, these mixtures can be produced in any rate unless mixing is limited by physical or chemical component properties, as also by valid safety specification[1]. Mixtures of argon (Ar), carbon-dioxide $\left(\mathrm{CO}_{2}\right)$, and/or oxygen $\left(\mathrm{O}_{2}\right)$ are often used for welding of microalloyed steels. Gas shielded arc welding in shielding atmosphere of argon usually does not provide stable arc that results in different defects forming, such as undercut, porosity and insufficient penetration and their effects on decreasing strength and ductility. Welding in protective gas mixtures $\mathrm{Ar}+\mathrm{CO}_{2}$ or $\mathrm{Ar}+\mathrm{CO}_{2}+\mathrm{O}_{2}$ provides better weld forming and less spattering than those obtained by welding in pure $\mathrm{CO}_{2}$, and comparing with welding in protective atmosphere of pure argon provides better penetration. Composition of gas mixture significantly affects weldment properties, especially weld metal toughness. Mechanical properties and toughness of weldment depend on microstructure of weld metal and HAZ. Many factors affect the structural changes $[2,3,4,5,6]$. Acicular ferrite is the most desirable morphology of ferrite, so this paper analyses influence 
of the composition of gas mixture on the ferrite modification in the weld metal, especially on the morphology of acicular ferrite [7]. This morphological form of ferrite is very significant, because it has great influence on the mechanical properties, particularly toughness. Namely, increased presence of oxide inclusions in weld metal, at least to a certain limit, promotes nucleation of acicular ferrite, which is well-known for its beneficial effect to both weld metal toughness and strength [8].

Therefore, the influence of gas mixture on weld metal microstructure and toughness has been investigated for hot-rolled microalloyed steels, welded by metal arc process with five different mixtures of shielded gases, comprising $\mathrm{Ar}, \mathrm{CO}_{2}$ and $\mathrm{O}_{2}$.

\section{EXPERIMENTAL PROCEDURE}

Hot rolled plates of microalloyed steel alloyed with $\mathrm{Nb}, \mathrm{V}$ and Ti were used for welding. The filler material was commercially available wire VAC $60 \mathrm{Ni} \emptyset 1,2 \mathrm{~mm}$ made by "Jesenice" - Slovenia (which has classification G3Ni1 according EN 440, SG-2 according DIN 8559 and ER 80 S-Nil according ASME/AWS 5.28). Their chemical composition and mechanical properties are given in Table 1 and Table 2.

Welding was performed by metal arc process with five different shielded gas mixtures, as shown in Table 3.

The input energy was kept in narrow range $7-9 \mathrm{~kJ} / \mathrm{cm}$ to exclude its influence since the weld metal toughness has been proved to be sensitive to input energy [8].

\begin{tabular}{cccccccccccc}
\hline element & $\mathrm{C}$ & $\mathrm{Si}$ & $\mathrm{Mn}$ & $\mathrm{P}$ & $\mathrm{S}$ & $\mathrm{Cu}$ & $\mathrm{Al}$ & $\mathrm{Nb}$ & $\mathrm{Ti}$ & $\mathrm{Ni}$ & $\mathrm{V}$ \\
\hline Base $\mathrm{m}$. & 0.056 & 0.32 & 1.28 & 0.012 & 0.005 & 0.031 & 0.049 & 0.045 & 0.02 & - & 0.054 \\
\hline $\begin{array}{c}\text { VAC 60 } \\
\mathrm{Ni}\end{array}$ & $0.08-0.1$ & - & $1.4-1.6$ & $\mathrm{P}+\mathrm{S}<0,025$ & - & - & - & - & $1-1.2$ & -
\end{tabular}

Table 1. Composition of base and filler materials

\begin{tabular}{ccccc}
\hline material & $\mathrm{Re},\left[\mathrm{N} / \mathrm{mm}^{2}\right]$ & $\mathrm{Rm},\left[\mathrm{N} / \mathrm{mm}^{2}\right]$ & $\mathrm{A}_{5},[\%]$ & $\mathrm{KV}\left(20^{\circ} \mathrm{C}\right),[\mathrm{J}]$ \\
\hline Base metal & $510-537$ & $571-595$ & $37-42$ & $152-197$ \\
\hline VAC 60 Ni & $440-510$ & $560-630$ & $22-30$ & $80-125,30-35\left(\right.$ at $\left.-40^{\circ} \mathrm{C}\right)$ \\
\hline
\end{tabular}

Table 2. Mechanical properties of base and filler materials

\begin{tabular}{cccc}
\hline \multirow{2}{*}{ No. of mixture } & \multicolumn{3}{c}{ volume content (vol \%) } \\
\cline { 2 - 4 } & $\mathrm{CO}_{2}$ & $\mathrm{O}_{2}$ & $\mathrm{Ar}$ \\
\hline 1 & 5.24 & - & balance \\
\hline 2 & 5.00 & 0.91 & balance \\
\hline 3 & 4.70 & 2.30 & balance \\
\hline 4 & 10.30 & - & balance \\
\hline 5 & 14.80 & - & balance \\
\hline
\end{tabular}

Table 3. Chemical compound of gas mixture
From all plates $\mathrm{V}$ notched specimens for weld metal toughness testing were produced, size according to the available material: $55 \times 10 \times 6 \mathrm{~mm}$. Obtained toughness values were transferred for comparison by regular procedure to standard specimen values. Toughness was determined on the Charpy pendulum with oscilloscope [9]. Tests were performed at room temperature $\left(20^{\circ} \mathrm{C}\right)$ and at $-55^{\circ} \mathrm{C}$.

\section{RESULTS AND DISCUSSION}

The microstructure of microalloyed steel, tested here, consists of acicular ferrite $(\mathrm{AF})$, proeutectoid ferrite $(\mathrm{PF})$ and ferrite with the secondary phase (FS), whose contents highly depend on gas mixture compound [10]. Figure 1 presents microstructures of the cover pass for different mixtures.

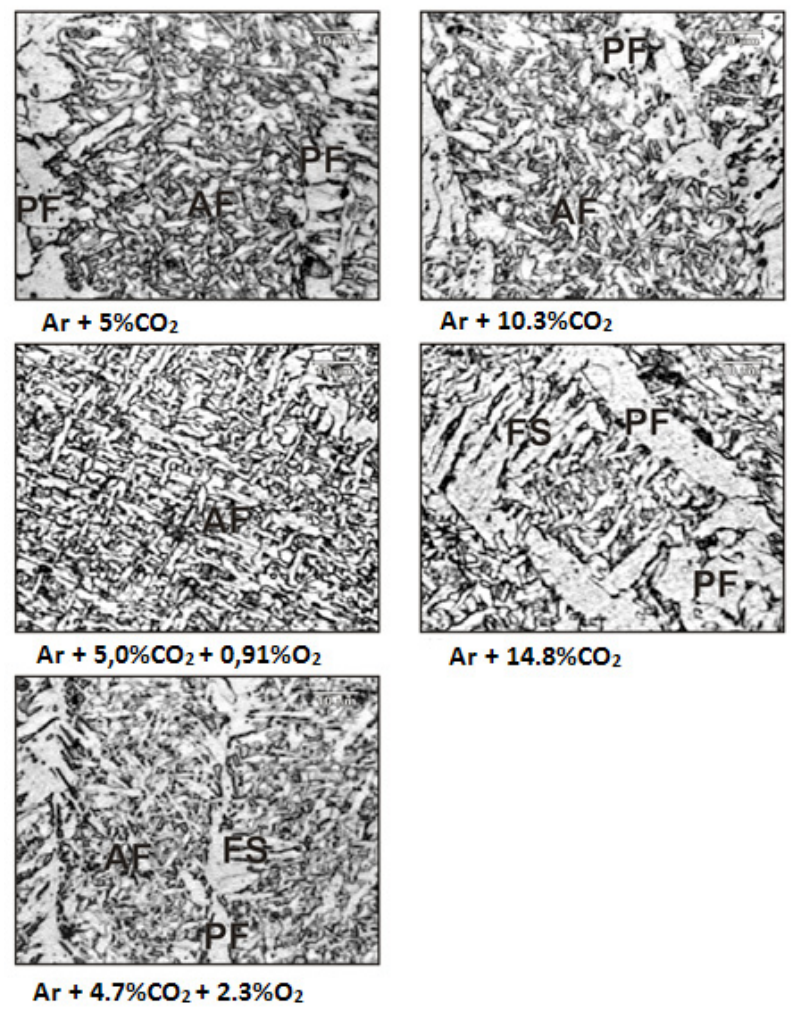

Figure 1. Microstructures of the cover pass for different mixtures

The highest content of AF corresponds to the gas mixture 2, being in accordance with the highest toughness, also obtained with gas mixture 2 [10]. The increase of oxygen content in a gas mixture increases number of inclusion sites and thus, the number of acicular ferrite nucleation sites, but only up to a certain limit. Above that limit, the opposite effect is noticable, namely AF content is reduced due to increased content of other ferrite 
morphologies, like ferrite with the secondary phase and proeutectoid ferrite $[5,10]$. For higher oxygen contents, the latter one has typical course microstructure, appearing in blocks (Fig. 1e). These observation are consistent with fact that increased oxygen equivalent effects on moving CCT diagram to shorter times [2].

Figure 2 shows the dependence between the change of volume content of AF in the cover pass and composition of gas mixture.

Volume content of AF in the cover pass of weld metal for all gas mixtures (78-83.3\% AF) is much higher than literature data [6] (50-60\% AF). Literature data are given for MIG weldments (process without oxygen), while this paper is giving data for weldments in shielding gases mixtures, with different active gases mixtures.

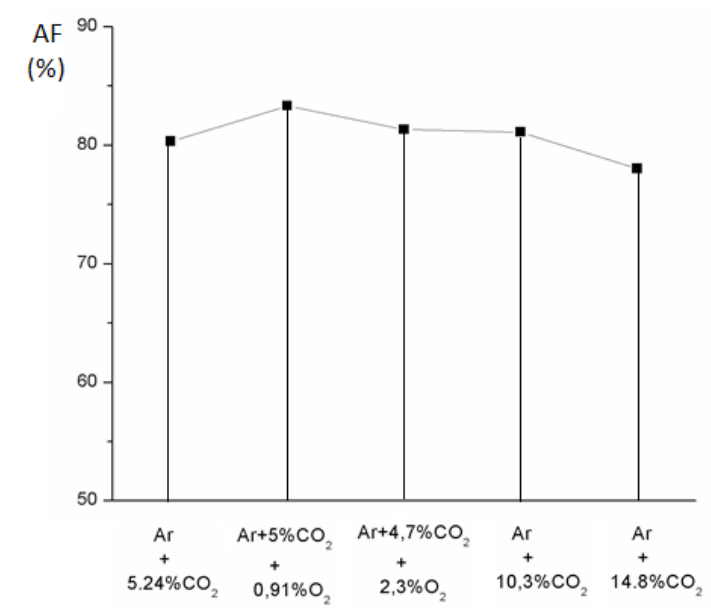

Figure 2. Dependence between change of volume content of AF in the cover pass and composition of gas mixture

Besides the noticed influence of composition of protective gasses on the microstructure, it is important to emphasize that the type of protective gas also affects metal weld toughness. Figure 3 presents the values of weld metal toughness $\left(\mathrm{E}_{\mathrm{u}}\right)$ at $+20^{\circ} \mathrm{C}$ and $-55^{\circ} \mathrm{C}$ for all compositions of gas mixtures.

Figure 3 shows the weld metal toughness changes as a function of composition of shielded gas. The highest toughness is achieved by welding in protective atmosphere 2 (energy $208 \mathrm{~J}$ at $20^{\circ} \mathrm{C}$ ), and the lowest toughness is achieved by welding in protective atmosphere 5 (166 $\mathrm{J}$ at $20^{\circ} \mathrm{C}$ ). The same dependence is characteristic for lower temperatures ( $93 \mathrm{~J}$ for protective atmosphere 2 and $58 \mathrm{~J}$ for protective atmosphere 5 ). With the oxygen content increase, toughness, firstly, increases but latter decreases, which is directly connected to the metal weld microstructure. The oxygen content increase affects the content increase of acicular ferrite in weld metal until the certain limit, and after that limit effects on the content decrease. The highest volume content of acicular ferrite $(\mathrm{AF})$ in the cover pass corresponds to the gas mixture 2 $(83,3 \%)$. On the contrary, the lowest volume content of $\mathrm{AF}$ is obtained with gas mixture $5(78 \%)$. The change of $\mathrm{AF}$ volume content in cover pass is in accordance with dependency between toughness and composition of gas mixtures.

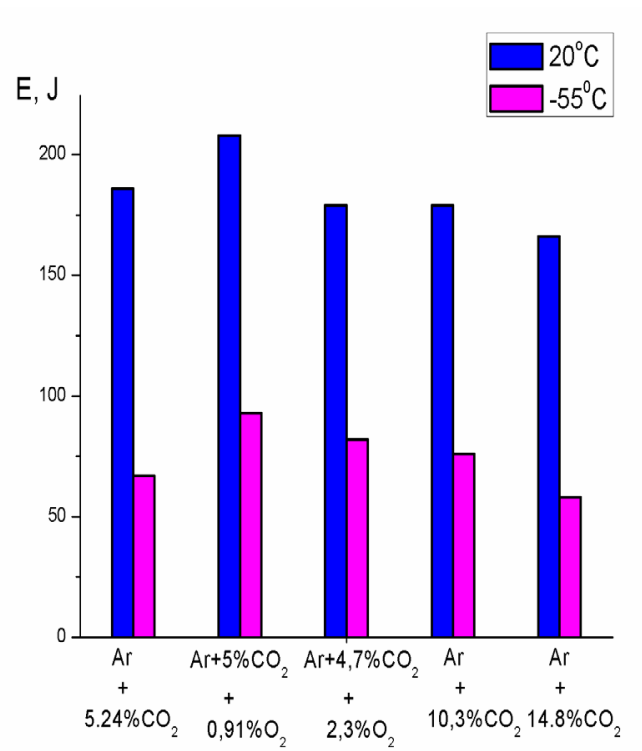

Figure 3. Values of weld metal toughness (E) at $+20^{\circ} \mathrm{C}$ and $-55^{\circ} \mathrm{C}$ for all compositions of gas mixtures

\section{CONCLUSIONS}

Based on the analysis of experimental results, the following conclusions can be derived:

1. The composition of gas mixture, i.e. oxygen content in shielding gas significantly affects weld metals properties, especially toughness and microstructure. This paper describes its effect to appearance of different ferrite morphologies and their content in weld metal microstructure, and effect on weld metal toughness.

2. In the weld metal microstructure, high volume content of AF has been noticed, but less contents of PF and FS. Dependency composition of shielding gas and volume content of AF in cover pass is between 78-83\%. The highest volume content of AF in cover pass of weld metals is obtained by welding with mixture $2\left(5.0 \% \mathrm{CO}_{2}+0.91 \% \mathrm{O}_{2}+\mathrm{Ar}\right)$, and that value could be taken as optimum. 
3. The type of protective gas affects metal weld toughness. The highest toughness is achieved by welding in protective atmosphere $2\left(5.0 \% \mathrm{CO}_{2}+0.91 \% \mathrm{O}_{2}+\right.$ $\mathrm{Ar})$ and the lowest toughness is achieved by welding in protective atmosphere $5\left(14.8 \% \mathrm{CO}_{2}+\mathrm{Ar}\right)$. The same dependance is observed at lower temperature $\left(-55^{\circ} \mathrm{C}\right)$.

4. The change of AF volume content in cover pass is in accordance with dependency between toughness and composition of gas mixtures.

\section{REFERENCES}

[1] R. Prokić Cvetković, A. Sedmak, O. Popović, Application of gas mixtures for gas shielded arc welding, 10th International Research/Expert Conference "Trends in the development of machinery and associated technology", Barcelona, Spain, 11-15 September, 2006

[2] M. I. Onsoen, S. Lui and D. L. Olson, Welding Journal (1996) 216.
[3] Z. Zhang and R. A. Ferrar, MST, Vol.12. (1996) 237.

[4] V.V. Podgaecki, Avtomatičeskaja svarka (1991) 455

[5] H.K.D.H. Bhadeshija, Beinit in Steels, The Institute of Materials, London (1992).

[6] Groupe of authors (Comitte of Welding Metallurgy of Japan Welding Society), Classification of Microstructures in Low C-Low Alloy Steel Weld Metal and Terminology, Doc. IX-1282-83.

[7] O. Popović, U. Lukić, R. Prokić Cvetković, The influence of heat on the content of acicular ferrite in weld metal of microalloyed steel, $18^{\text {th }}$ International research conference "Trends in the development of machinery and associated technology", Budapest, Hungary, 10-12 September, 2014.

[8] R. Prokić-Cvetković, A. Milosavljević, A. Sedmak, Z. Burzić, Zavarivanje i Zavarene Konstrukcije, 3, (in Serbian) (2000) 107

[9] D. A.Fleming, A. Q. Bracarense, S. Liu, D.L.Olson., Welding Journal, Vol. 75, No. 6, (1996) 171

[10] R.Prokić-Cvetković, PhD Thesis, Fac. of Mech. Eng., Belgrade (2000). 